\title{
Depois da fotografia: uma literatura fora de si, Natália Brizuela
}

\author{
Afterphotography: a literature outside itself, by Natália Brizuela \\ Después de la imagen: una literatura fuera de sí mismo, de Natália Brizuela
}

Carolina Martins Etcheverry

Depois da fotografia: uma literatura fora de si, livro escrito na forma de ensaio, busca analisar e problematizar a questão das fronteiras entre as diferentes linguagens, notadamente a literatura e a fotografia. Natalia Brizuela, professora da Universidade da Califórnia, em Berkeley, já é conhecida no Brasil por sua publicação Fotografia e Império: paisagens para um Brasil Moderno (Cia das Letras, 2012), em que aborda questões atinentes à produção e circulação de fotografias no Brasil do século XIX.

Em Depois da fotografia, temos a proposta de pensar as fronteiras entre a literatura e as outras artes, fazendo-nos perceber como os limites entre elas, atualmente, podem ser entendidos como uma zona porosa, que permite diversas contaminações. A proposta de Brizuela leva-nos a conhecer o trabalho de diversos escritores latino-americanos (Mario Bellatin, Diamela Eltit, Nuno Ramos e Juan
Rulfo) e como, em suas obras, a fotografia aparece em meio à escrita.

Na primeira parte, temos um pequeno ensaio sobre como a escrita assume a categoria de prática artística e sua relação com outra linguagem, a fotografia. A partir do escritor mexicano Mario Bellatin, criador da Escola Dinâmica de Escritores, Brizuela mostra o apagamento das fronteiras que separam as artes entre si, a partir de cruzamentos e passagens que servem para a desestruturação das categorias antes estanques. Segundo a autora,

\footnotetext{
Doutora em História pela Pontifícia Universidade Católica do Rio Grande do Sul, Brasil. Bolsista do Programa Nacional de Pós-Doutorado no Programa de Pós-Graduação em História da Pontifícia Universidade Católica do Rio Grande do Sul.

Recebido em 01/04/2016 - Aprovado em 01/09/2016 http://dx.doi.org/10.5335/hdtv.16n.2.
} 
[...] o que me interessa explorar aqui são as lógicas e mecanismos dessas transformações, desses cruzamentos, e assinalar em particular alguns deslocamentos e metamorfoses nessa atividade da arte que chamamos literatura (BRIZUELA, 2014, p. 15).

Nos romances analisados no livro, a fotografia ocupa lugar expressivo, pois proporciona uma "passagem ao que não é", faz com que a literatura, como diz o título do livro, saia de si e explore outras linguagens. Na obra de Mario Bellatin, a fotografia, segundo a autora, aparece como uma forma de deslocar a escrita, de levá-la para fora de sua própria linguagem. No caso desse escritor, as fotografias integram seus livros (Perros héroes, Los fantasmas del masajista, Shiki Nagaoka: una nariz de ficción e Demerol). Shiki Nagaoka, por exemplo, é um livro bastante exemplar dessa nova escrita, uma vez que o personagem principal estava obcecado pelas relações entre linguagem, fotografia e literatura. Trata-se de uma pseudobiografia, na qual Bellatin narra a vida de um escritor fictício, que reflete sobre a escrita e sobre o papel da fotografia na escrita:

O narrador de Shiki Nagaoka: una nariz de ficción diz, relatando as opiniões do personagem principal, que no porvir o escritor fará (não escreverá, mas fará) fotografias narrativas: 'A fotografia narrativa tenta realmente estabelecer um novo tipo de meio, alternativo à palavra escrita, e que talvez aquela seja a forma como serão concebidos os livros no futuro'. Um modo alternativo à palavra escrita: uma fotografia escrita (BRIZUELA, 2014, p. 17).

A fotografia funcionaria como desestabilizadora no romance pseudobiográfico. Uma vez que, desde o seu surgimento, a fotografia encontra-se em uma "prisão documental", devido à crença de que ela era uma cópia fiel da realidade, ao inserir uma fotografia em um livro espera-se que ela referende o que ali está escrito, que sirva como prova do que está sendo dito. É esse o papel das fotografias em Shiki Nagaoka: atestar que o personagem é uma pessoa real, que existe no mundo. No entanto, ao saber que estamos diante de uma pseudobiografia, a fotografia proporciona um outro entendimento sobre si, uma "desfamiliarização da realidade", uma descontinuidade.

A autora entende a fotografia como "índice de opacidade", pois os documentos indexicais (a fotografia entendida aqui como um índice no sentido peirciano) não revelam, ao contrário, escondem a realidade. "É a certeza que sabe que não se pode saber" (BRIZUELA, 2014, p. 27). Entende-se, assim, que a fotografia não é documento, mas ficção que emerge da realidade (e não da imaginação, como na literatura). A característica contraditória da fotografia (pertencer ao mundo, mas não ser o mundo; ser familiar, mas também ser estranha) é o que, segundo a autora, permite insistir na opacidade da ficção e, também, na opacidade da realidade.

As expansões da literatura (utilizando termo cunhado por Rosalind Krauss para falar da escultura) são variadas e não acontecem apenas a partir dos anos 1950, senão vem acontecendo, em experiências isoladas, desde o início do século $X X$ - a primeira edição de Os sertões, de Euclides da Cunha, de 1902, por exemplo, tinha fotografias da Guerra de Canudos, que em edições posteriores foram suprimidas. Mas é a partir dos 
anos 1950 que a prática torna-se mais frequente na literatura.

Mas como acontece essa contaminação entre a literatura e a fotografia? São diversas as maneiras. Pode acontecer por meio da inclusão de fotografias em obras literárias ou como

[...] paradigma de uma nova sintaxe e de uma nova literatura utilizando certas características do dispositivo fotográfico como a indexicalidade, o corte, o ponto de vista, o pôr em cena, a dupla temporalidade (passado-presente/o que foi - o agora), o caráter documental, sua função mnemônica, o ser uma mensagem sem código (BRIZUELA, 2014, p. 31).

Em Pedro Páramo, de Juan Rulfo, por exemplo, a sintaxe e a forma estruturam-se pela fotografia, mesmo que nenhuma fotografia esteja nele presente.

Da segunda metade do século XX em diante a fotografia (e a televisão, um pouco depois) entram para a vida cotidiana, tornando o ver imagens algo comum. Nesse sentido, o livro nos propõe pensar a presença de fotografias na literatura e a inserção da fotografia no campo artístico, não como arte, mas como conceito e como forma de registro de outras práticas artísticas, como a performance. A partir disso, a autora quer pensar no porquê de a literatura ter recorrido tantas vezes à fotografia, uma vez que essa contaminação talvez lhe retirasse a autonomia.

De que modo há uma ruptura e destruição da sintaxe das diferentes artes, e porque, a partir da metade do século $X X$, a especificidade dos meios entra em crise, havendo uma necessidade de aproximações diversas? Esse é, grosso modo, o resumo da proposta que Brizuela nos faz na primeira parte de seu ensaio. Para esboçar uma resposta, os capítulos subsequentes nos apresentam casos em que a literatura incorpora a fotografia, fazendo com que haja uma expansão de ambas as linguagens.

Juan Rulfo, escritor mexicano, autor, entre outros, de Pedro Páramo, também era fotógrafo. A autora propõe uma "narrativa fotográfica" para entender o papel da fotografia na escrita de Rulfo, ainda que ela não esteja presente em reproduções ao longo do livro. Suas fotografias foram muitas vezes entendidas como uma ilustração de sua escrita, porém, Brizuela propõe-se a pensar a fotografia em Rulfo "ao refletir sobre sua escrita a partir de certos procedimentos fotográficos" (BRIZUELA, 2014, p. 116). Assim, a partir da ideia de fragmento, de montagem e da temporalidade da fotografia é que a autora consegue pensar sobre a relação da literatura e da fotografia na obra de Rulfo.

Em Diamela Eltit podemos perceber outra maneira a partir da qual há uma contaminação entre as linguagens literária e fotográfica, incluindo, dessa vez, o teatro. Há, nesse caso, uma crítica ao formato livro, de que ele não seria suficiente para dar conta daquilo que Eltit queria escrever diante do contexto político e social pelo qual passava o Chile nos anos 1970. A escritora recorre, então, a diversos recursos, entre eles leituras orais em espaços públicos, performances, trabalhos em vídeo. $\mathrm{O}$ recurso à teatralidade lhe serve como estratégia de desunificação, de expansão.

A proposta de Natalia Brizuela mostra-se bastante pertinente e atual, uma vez que os cruzamentos entre as linguagens - entre literatura e fotografia, mas também entre 
fotografia e artes visuais, entre literatura e teatro e muitas outras possibilidades - são resultado de um processo longo de mutação na nossa forma de produzir e de perceber a literatura e a visualidade. Não encaixamos mais as linguagens em espaços estanques, como se queria no século XIX, mas percebemos os cruzamentos entre elas.

Brizuela traz aportes importantes para pensar a fotografia para além da ideia de documento, apresentando-a, a partir de diversos autores, como um recorte, um fragmento de algo que já passou. Esse recorte, no entanto, não é limitador da imaginação, uma vez que permite a projeção do espectador. É por isso, talvez, que a literatura tenha recorrido à fotografia na busca de expandir suas formas de representação. A fotografia contribui para que a literatura questione, por exemplo, a própria ideia de realidade e ficção, desestruturando o leitor.

\section{Referência}

BRIZUELA, Natalia. Depois da fotografia: uma literatura fora de si. Rio de Janeiro: Rocco, 2014. 